\title{
BEBAN KERJA MENTAL DAN PENDAPATAN DENGAN KEBAHAGIAAN DI TEMPAT KERJA PADA DOSEN DI UNIVERSITAS JEMBER
}

\section{MENTAL WORKLOAD AND SALARY WITH HAPPINESS AT WORKPLACE AT UNIVERSITY OF JEMBER LECTURERS}

\author{
Dwi Sterida Mahani ${ }^{1 *}$, Isa Ma'rufi ${ }^{2}$, Reny Indrayani ${ }^{3}$ \\ ${ }^{123}$ Program Studi Ilmu Kesehatan Masyarakat Fakultas Kesehatan Masyarakat \\ Universitas Jember \\ *email: sterida19@gmail.com
}

\begin{abstract}
Happiness at work is a mindset which allows you to maximize performance and achieve potential. Lecturers who have happiness at work will have employee engagement to their job, persevering, enthusiasm, and full concentration to complete their work. The purpose of this research wa analyze the correlation between mental workload, incomes with happiness at workplace to University of Jember lecturers. This research was an observational analytic study and used a cross sectional research design. The population in this research was active lecturers with a total of 939 lecturers while the samples were 90 lecturers. The results showed that most respondent were female, respondents were in the early adult category at the age of 20-40 years, most have a long service life $>10$ years, the majority have group III, most served as assistant professor, most of the mental workload were in the moderate category and the income earned by lectures was in the range Rp 5.000.000,- to $R p$ 10.000.000,-. Spearman test result that mental workload has a significant correlation with happiness at workplace. The University of Jember should make a better institutional governance and for the lecturers were expected to apply a better time management.
\end{abstract}

Keyword: Mental workload, incomes, happiness at workplace

\begin{abstract}
Abstrak
Kebahagiaan di tempat kerja adalah pola pikir seseorang untuk memaksimalkan potensi diri dan kinerja. Dosen yang mempunyai kebahagiaan di tempat kerja akan memiliki keterikatan yang tinggi dengan pekerjaannya, semangat, antusias, tekun dan berkonsentrasi penuh untuk menyelesaikan pekerjaannya. Tujuan penelitian ini adalah untuk menganalisis beban kerja mental dan pendapatan dengan kebahagiaan di tempat kerja pada Dosen di Universitas Jember. Jenis penelitian ini yaitu analitik observasional dengan menggunakan desain penelitian cross sectional. Populasi penelitian ini yaitu Dosen di Universitas Jember yang berstatus aktif dengan jumlah 939 dosen sedangkan sampel yang diambil yaitu 90 responden. Hasil penelitian menunjukkan bahwa paling banyak responden berjenis kelamin perempuan, berada pada kategori dewasa awal yaitu pada usia 20-40 tahun, paling banyak memiliki masa kerja lama >10 tahun, mayoritas mempunyai golongan III, paling banyak menjabat sebagai lektor, sebagian besar beban kerja mental berada pada kategori sedang dan pendapatan yang diperoleh dosen berada pada rentang Rp 5.000.000,- s/d Rp 10.000.000,-. Hasil uji korelasi Spearman menunjukkan bahwa terdapat hubungan antara beban kerja mental dengan kebahagiaan di tempat kerja. Pihak Universitas Jember diharapkan dapat meningkatkan tata kelola lembaga yang lebih baik serta diharapkan dosen dapat menerapkan manajemen yang lebih baik lagi.

Kata Kunci: Beban kerja mental, pendapatan, kebahagiaan di tempat kerja
\end{abstract}

\section{PENDAHULUAN}

Dosen adalah tenaga pendidik tingkat perguruan tinggi yang merupakan komponen utama dalam sistem perguruan tinggi di Indonesia. Berdasarkan UU RI No. 14 Tahun
2005 Tentang Guru dan Dosen menyatakan bahwa dosen mempunyai tugas pokok untuk menjalankan Tridharma Perguruan Tinggi yang meliputi pengajaran dan pendidikan, melaksanakan penelitian dan pengabdian 
masyarakat serta tugas penunjang lain berdasarkan Tridharma Perguruan Tinggi (Menteri Hukum dan Hak Asasi Manusia, 2005).

Perguruan tinggi negeri terbesar di Kabupaten Jember adalah Universitas Jember yang memiliki 15 fakultas dengan 103 program studi, serta jumlah mahasiswa pada periode 2018/2019 sebanyak 33.928 mahasiswa pada jenjang diploma, sarjana dan magister. Selain merupakan perguruan tinggi negeri terbesar di Kabupaten Jember, Universitas Jember juga merupakan perguruan tinggi negeri terbaik di Kabupaten Jember dengan status akreditasi A pada tahun 2015. Menjadi perguruan tinggi yang terbaik tentu memberikan tuntutan tersendiri bagi Universitas Jember untuk selalu meningkatkan kualitas dari segi sarana prasarana, prestasi mahasiswa maupun peran dosen yang sangat penting.

Jumlah mahasiswa di Universitas Jember adalah 33.928 terhitung semester genap periode 2018/2019 bulan Maret yang sedang menempuh pendidikan diploma, S1, magister maupun doktor. Jumlah dosen aktif di Universitas Jember berjumlah 1070 dosen. Peraturan Menteri Riset, Teknologi dan Pendidikan Tinggi No. 2 Tahun 2016 menyatakan bahwa rasio ideal untuk dosen terhadap mahasiswa yaitu 1:45 untuk rumpun ilmu sosial ilmu humaniora dan 1:30 untuk rumpun ilmu eksakta. Berdasarkan rasio ideal untuk dosen terhadap mahasiswa tersebut, dari 15 fakultas di Universitas Jember terdapat empat fakultas dari rumpun sosial humaniora dan empat fakultas dari rumpun ilmu eksakta yang memiliki rasio dosen dan mahasiswa tidak ideal.

Beban kerja yang dimiliki dosen merupakan dominan pada beban kerja mental karena penugasan dan kewajiban dosen dominan pada pekerjaan yang berhubungan dengan mental dari pada fisik (Dewi, 2016). Pedoman pelaksanaan penilaian Beban Kerja Dosen (BKD) Universitas Jember 2018 menyatakan bahwa beban kerja yang harus dipenuhi setiap dosen setara dengan 12-16 SKS per semester dengan rincian 9 SKS pendidikan dan penelitian, 1 SKS pengabdian dan 2 SKS kegiatan penunjang Tridharma Perguruan Tinggi. Hasil wawancara pada penelitian ini menyampaikan bahwa pada kenyataannya beban kerja yang dimiliki dosen lebih dari kewajiban yang harus dipenuhi yaitu 12-16 SKS, terutama pada bidang pendidikan dan pengajaran. Fenomena ini akan terjadi terutama pada fakultas yang rasio antara jumlah dosen dan mahasiswa tidak ideal. Beban kerja terus bertambah ketika dosen mempunyai tugas tambahan baik secara struktural maupun non struktural.

Gaji adalah balas jasa yang diberikan secara berkala setiap satu bulan sekali kepada karyawan yang sudah ditetapkan (Priyono and Marnis, 2008). Penentuan gaji untuk dosen PNS mengacu pada PP No. 30 Tahun 2015. Rincian gaji yang diterima dosen meliputi gaji pokok, tunjangan fungsional, tunjangan struktural, sertifikasi dosen dan pendapatan lain jika menjalankan tugas tambahan sehingga setiap dosen akan membawa take home pay yang berbeda-beda. Penelitian dari University of California menunjukkan bahwa $92 \%$ responden setuju bahwa gaji menentukan kebahagiaan dan kepuasan kerja (Guswandy, 2017). Hal ini sesuai dengan penelitian Lintangsari (2012) bahwa gaji merupakan faktor utama yang dapat membuat karyawan bahagia di perusahaan.

Veenhoven (2006) mendefinisikan kebahagiaan sebagai persepsi seseorang untuk menilai sejauh mana ia memiliki energi positif dari dalam dan luar. Kebahagiaan adalah kualitas hidup pada individu untuk menjadi lebih berkembang dari berbagai aspek yaitu peningkatan kesehatan, kreativitas dan pendapatan yang tinggi serta tempat kerja yang baik. Menurut Pryce and Jones (2010) kebahagiaan di tempat kerja adalah pola pikir seseorang untuk memaksimalkan potensi diri dan kinerja. Karakteristik bahagia di tempat kerja yaitu lebih produktif, tingkat absensi rendah, bersemangat untuk melakukan pekerjaan, kepuasan kerja. Motivasi kerja yang tinggi serta melakukan pekerjaan secara efektif dan efisien (Pryce and Jones, 2010).

Dosen yang mempunyai kebahagiaan di tempat kerja akan memiliki keterikatan yang tinggi dengan pekerjaannya, semangat, antusias, tekun mengerjakan tugas-tugasnya, berkonsentrasi penuh untuk menyelesaikn tugas-tugasnya, memberikan dampak positif, berpeluang kecil untuk melepaskan pekerjaan serta meningkatkan produktivitas. Hasil wawancara dengan responden pada penelitian ini menunjukkan bahwa berkarir menjadi dosen merupakan profesi yang menyenangkan karena memiliki fleksibilitas waktu dan tempat, dapat sedekah ilmu, menjadikan kehidupan, menambah wawasan, berkesempatan mengembangkan diri di bidang pendidikan dan bakat serta dapat berinteraksi dengan 
mahasiswa yang dapat memberikan energi positif tersendiri bagi dosen.

Berdasarkan latar belakang tersebut, dosen dijadikan subjek penelitian karena dosen merupakan tenaga pendidik di level perguruan tinggi yang mempunyai kewajiban untuk melaksanakan Tridharma Perguruan Tinggi. Beban kerja dan intensitas yang dimiliki dosen beragam dan membutuhkan kesabaran, usaha ekstra dalam melaksanakan pekerjaannya karena sebagai dosen diharuskan untuk melayani dan memberikan kepuasan kepada mahasiswa serta melakukan beberapa tugasnya di luar jam kerja (Sulistyowati and Muazansyah, 2018). Upaya optimal dibutuhkan untuk menjalankan tugas utama dosen sesuai dengan tridharma perguruan tinggi, selain kewajiban tersebut dosen juga mempunyai kewajiban untuk berperan andil dalam keluarga.

Tujuan dari penelitian ini adalah untuk menganalisis hubungan beban kerja mental dan pendapatan dengan kebahagiaan di tempat kerja pada Dosen di Universitas Jember.

\section{METODE PENELITIAN}

Jenis penelitian ini yaitu analitik observasional dengan menggunakan pendekatan kuantitatif. Populasi penelitian ini yaitu Dosen di Universitas Jember yang sudah PNS yang berjumlah 1070 dosen. Sampel penelitian yang diambil sebanyak 90 responden. Teknik pengambilan sampel proporsional random sampling dengan kriteria eksklusi yaitu dosen yang sedang cuti, izin belajar dan tugas belajar.

Variabel bebas yang digunakan pada penelitian ini adalah karakteristik individu (jenis kelamin, usia, masa kerja, golongan dan jabatan fungsional), beban kerja mental dan pendapatan. Variabel terikat dalam penelitian ini adalah kebahagiaan di tempat kerja

Data primer pada penelitian ini yaitu berupa informasi dari hasil wawancara, hasil angket sedangkan data sekunder berupa studi dokumentasi mengenai jumlah dosen dan standar biaya Universitas Jember. Pengukuran beban kerja mental menggunakan metode NASA-TLX dan pengukuran kebahagiaan di tempat kerja menggunakan kuesioner Oxford Happiness Questionnaire (OHQ) oleh Hills and Argyle (2002).

Pengumpulan data dilakukan oleh peneliti dengan dibantu teman sejawat. Penelitian dilaksanakan pada Bulan September-Oktober 2019 pada jam kerja yaitu 07.00 - 16.00 WIB. Data dianalisis menggunakan analisis univariat dan bivariat. Analisis univariat untuk mendeskripsikan karakteristik individu, beban kerja mental, pendapatan dan kebahagiaan dit tempat kerja. Analisis bivariat dilakukan dengan menggunakan uji statistik Spearman dan Chi Square untuk menguji hubungan antara variabel bebas dan variabel terikat.

\section{HASIL PENELITIAN}

\section{Karakteristik Responden}

Karakteristik responden adalah ciri-ciri umum yang dimiliki responden sebagai bagian dari identitas dirinya. Karakteristik responden dalam penelitian ini terdiri dari jenis kelamin, usia, masa kerja, golongan dan jabatan fungsional.

Tabel 1. Distribusi Frekuensi Karakteristik Responden

\begin{tabular}{lcc}
\hline \multicolumn{1}{c}{$\begin{array}{c}\text { Karakteristik } \\
\text { Responden }\end{array}$} & $\mathrm{n}$ & $\%$ \\
\hline Jenis Kelamin & & \\
\hline Laki-laki & 43 & 48 \\
Perempuan & 47 & 52 \\
\hline Usia (tahun) & 51 & 57 \\
\hline $20-40$ & 35 & 39 \\
$41-60$ & 4 & 4 \\
$>60$ & & \\
\hline Masa Kerja (tahun) & 23 & 26 \\
\hline < 5 tahun & 22 & 24 \\
5 - 10 tahun & 45 & 50 \\
$>10$ tahun & & \\
\hline Golongan & 75 & 83 \\
\hline Golongan III & 15 & 17 \\
Golongan IV & & \\
\hline Jabatan Fungsional & 18 & 20 \\
\hline PNS belum punya & 18 & 20 \\
fungsional & 15 & 42 \\
Asisten Ahli & 17 \\
Lektor & 1 \\
Lektor Kepala & 15 \\
Guru Besar & \\
\hline
\end{tabular}

Tabel 1 menunjukkan bahwa jenis kelamin terbanyak yaitu perempuan sebesar 52\% sebanyak 47 responden, berdasarkan usia berada pada kategori dewasa awal yaitu pada usia 20-40 tahun sebesar 57\% yaitu sebanyak 51 responden, persentase terbanyak responden berdasarkan masa kerja yaitu mempunyai masa kerja lama yaitu >10 tahun sebesar 50\% sebanyak 45 responden, mayoritas responden mempunyai golongan III sebesar $83 \%$ yaitu sebanyak 75 responden, dan distribusi responden berdasarkan jabatan fungsional menunjukkan bahwa paling banyak responden 
memiliki jabatan fungsional sebagai lektor sebesar $42 \%$ yaitu sebanyak 38 responden.

\section{Beban Kerja Mental}

Identifikasi beban kerja mental pada penelitian ini dibagi menjadi tiga kategori yaitu beban kerja mental ringan (skor <50), beban kerja mental sedang (skor 50-80) dan beban kerja mental berat (skor >80). Distribusi responden berdasarkan beban kerja mental disajikan oleh Tabel 2.

Tabel 2 menunjukkan bahwa sebagian besar responden mempunyai beban kerja mental sedang sebesar $78 \%$ yaitu sebanyak 70 responden.

Tabel 2. Distribusi Responden Berdasarkan Beban Kerja Mental

\begin{tabular}{lcc}
\hline \multicolumn{1}{c}{$\begin{array}{c}\text { Beban Kerja } \\
\text { Mental }\end{array}$} & $\mathrm{n}$ & $\%$ \\
\hline Ringan & 15 & 18 \\
Sedang & 71 & 78 \\
Berat & 4 & 4 \\
\hline
\end{tabular}

\section{Pendapatan}

Identifikasi pendapatan pada penelitian ini dibagi menjadi tiga kategori yaitu $<\mathrm{Rp}$ $5.000 .000,-\quad ; \quad \mathrm{Rp} 5.000 .000,-\quad \mathrm{s} / \mathrm{d} \quad \mathrm{Rp}$ 10.000.000,- dan > Rp 10.000.000,-. Hasil identifikasi disajikan pada Tabel 3 sebagai berikut:

Tabel 3. Distribusi Resonden Berdasarkan Pendapatan

\begin{tabular}{lcc}
\hline \multicolumn{1}{c}{ Pendapatan } & $\mathrm{n}$ & $\%$ \\
\hline < Rp 5.000.000,- & 28 & 31 \\
Rp 5.000.000,- s/d Rp & 56 & 62 \\
10.000.000,- & 6 & 7 \\
> Rp 10.000.000,- & 6 & \\
\hline
\end{tabular}

Berdasarkan hasil penelitian menunjukkan bahwa paling banyak responden memiliki pendapatan antara $\mathrm{Rp} 5.000 .000,-\mathrm{s} / \mathrm{d} \mathrm{Rp}$ 10.000.000,- sebesar $62 \%$ yaitu sebanyak 55 responden.

\section{Kebahagiaan di Tempat Kerja}

Identifikasi kebahagiaan di tempat kerja responden pada penelitian ini disajikan pada Tabel 4. Kebahagiaan ditempat kerja dibagi menjadi tiga kategori yaitu kebahagiaan di tempat kerja rendah (skor 0-57), kebahagiaan di tempat kerja sedang (skor 58-116) dan kebahagiaan di tempat kerja tinggi. (skor 117174).
Tabel 4. Distribusi Responden Berdasarkan Kebahagiaan di Tempat Kerja

\begin{tabular}{lcc}
\hline $\begin{array}{c}\text { Kebahagiaan di } \\
\text { Tempat Kerja }\end{array}$ & $\mathrm{n}$ & $\%$ \\
\hline Sedang & 10 & 11 \\
Tinggi & 80 & 89 \\
\hline
\end{tabular}

Berdasarkan hasil penelitian menunjukkan bahwa mayoritas responden mempunyai kebahagiaan tinggi di tempat kerja sebesar $89 \%$ yaitu sebanyak 80 responden. Hanya ada $11 \%$ responden yang memiliki kebahagiaan yang sedang yaitu sebanyak 10 responden.

\section{Hubungan Karakteristik Responden dengan Kebahagiaan di Tempat Kerja}

a. Hubungan Jenis Kelamin dengan Kebahagiaan di Tempat Kerja

Hasil dari hubungan antara jenis kelamin dengan kebahagian di tempat kerja disajikan pada Tabel 5 berikut:

Tabel 5. Hubungan Jenis Kelamin dengan Kebahagiaan di Tempat Kerja

\begin{tabular}{cccccc}
\hline \multirow{2}{*}{$\begin{array}{c}\text { Jenis } \\
\text { Kelamin }\end{array}$} & \multicolumn{4}{c}{ Kebahagiaan di Tempat } & \multirow{2}{*}{$\begin{array}{c}\text { Chi- } \\
\text { Kerja }\end{array}$} \\
\cline { 2 - 5 } & Sedang & \multicolumn{2}{c}{ Tinggi } & Square \\
\cline { 2 - 5 } & $\mathrm{n}$ & $\%$ & $\mathrm{n}$ & $\%$ & p-value \\
\hline Laki-laki & 4 & 40 & 39 & 48.75 & 0.314 \\
Perempuan & 6 & 60 & 41 & 51.25 & \\
\hline
\end{tabular}

Berdasarkan hasil tabulasi silang yang ditunjukkan pada Tabel 5 . sebagian besar responden berjenis kelamin perempuan sebesar $51.25 \%$ yaitu sebanyak 41 responden. Hasil analisis data dengan uji Chi-Square menunjukkan bahwa variabel jenis kelamin dengan kebahagiaan di tempat kerja tidak mempunyai hubungan yang signifikan karena p-value $(0.314)>\alpha(0.05)$.

b. Hubungan Usia dengan Kebahagiaan di Tempat Kerja

Tabel 6. Hubungan Usia dengan Kebahagiaan di Tempat Kerja

\begin{tabular}{lll}
\hline & $\begin{array}{l}\text { Skor Kebahagiaan } \\
\text { Tempat Kerja }\end{array}$ \\
\hline Usia & $\mathrm{r}=0.059$ \\
& $\mathrm{p}=0.582$ \\
& $\mathrm{n}=90$ & \\
&
\end{tabular}

Berdasarkan hasil analisis korelasi Spearman pada Tabel 6, tidak terdapat hubungan antara variabel usia dengan kebahagiaan di tempat kerja dengan nilai 
p-value sebesar 0.582 yang menunjukkan tidak signifikan karena p-value $(0.582)>\alpha(0.05)$.

c. Hubungan Masa Kerja dengan Kebahagiaan di Tempat Kerja

Tabel 7. Hubungan Masa Kerja dengan Kebahagiaan di Tempat Kerja

\begin{tabular}{lll}
\hline & $\begin{array}{l}\text { Skor Kebahagiaan } \\
\text { Tempat Kerja }\end{array}$ \\
\hline Masa & $\mathrm{r}=0.080$ \\
Kerja & $\mathrm{p}=0.454$ \\
& $\mathrm{n}=90$ & \\
\hline
\end{tabular}

Berdasarkan hasil analisis korelasi Spearman pada Tabel 7, tidak terdapat hubungan antara masa kerja dengan kebahagiaan di tempat kerja dengan nilai pvalue 0.454 yang menunjukkan tidak signifikan karena p-value $>\alpha(0.05)$.

d. Hubungan Golongan dengan Kebahagiaan di Tempat Kerja

Hubungan golongan dengan kebahagiaan kerja responden disajikan oleh Tabel 8 yang menunjukkan bahwa sebagian besar responden memiliki golongan III dengan kebahagiaan tinggi di tempat kerja sebesar $81.25 \% \%$ yaitu 65 responden. Hasil analisis data dengan uji
Chi-Square menunjukkan bahwa tidak terdapat hubungan antara golongan dengan kebahagiaan di tempat kerja dengan p-value $(0.145)>\alpha$ (0.05)

Tabel 8. Hubungan Golongan dengan Kebahagiaan di Tempat Kerja

\begin{tabular}{lccccc}
\hline \multirow{2}{*}{ Golongan } & \multicolumn{4}{c}{ Kebahagiaan di Tempat } & \multirow{2}{*}{$\begin{array}{c}\text { Chi- } \\
\text { Serja }\end{array}$} \\
\cline { 2 - 5 } & \multicolumn{2}{c}{ Sedang } & \multicolumn{2}{c}{ Tinggi } & \\
\cline { 2 - 5 } & $\mathrm{n}$ & $\%$ & $\mathrm{n}$ & $\%$ & p-value \\
\hline Gol. III & 10 & 100 & 65 & 81.25 & \multirow{2}{*}{0.145} \\
Gol. IV & 0 & 0 & 15 & 18.75 & \\
\hline
\end{tabular}

e. Hubungan Jabatan Fungsional dengan

Kebahagiaan di Tempat Kerja

Tabel 9 menunjukkan tabulasi silang antara jabatan fungsional dengan kebahagiaan di tempat kerja pada dosen di Universitas Jember yaitu bahwa sebagian besar responden memiliki jabatan fungsional lektor sebesar 42.5\% sebanyak 34 responden. Hasil analisis data dengan uji Mann Whitney menunjukkan bahwa tidak terdapat hubungan variabel jabatan fungsional dengan kebahagiaan di tempat kerja dengan nilai $p$-value $(0.373)>\alpha(0.05)$.

Tabel 9. Hubungan Golongan dengan Kebahagiaan di Tempat Kerja

\begin{tabular}{|c|c|c|c|c|c|}
\hline \multirow[t]{3}{*}{ Jabatan Fungsional } & \multicolumn{4}{|c|}{ Kebahagiaan di Tempat Kerja } & \multirow{3}{*}{$\begin{array}{c}\text { Mann Whit } \\
\text { ney } \\
\text { p-value }\end{array}$} \\
\hline & \multicolumn{2}{|c|}{ Sedang } & \multicolumn{2}{|c|}{ Tinggi } & \\
\hline & $\mathrm{n}$ & $\%$ & $\mathrm{n}$ & $\%$ & \\
\hline PNS belum punya fungsional & 4 & 40 & 14 & 17.5 & \\
\hline Asisten Ahli & 1 & 10 & 17 & 21.25 & \\
\hline Lektor & 4 & 40 & 34 & 42.5 & 0.373 \\
\hline Lektor Kepala & 1 & 10 & 14 & 17.5 & \\
\hline Guru Besar & 0 & 0 & 1 & 1.25 & \\
\hline
\end{tabular}

Hubungan Beban Kerja Mental dengan Kebahagiaan di Tempat Kerja

Tabel 10. Hubungan Beban Kerja Mental dengan Kebahagiaan di Tempat Kerja

\begin{tabular}{lll}
\hline & $\begin{array}{l}\text { Skor Kebahagiaan } \\
\text { Tempat Kerja }\end{array}$ \\
\hline Skor Beban & $\mathrm{r}=-0.221$ \\
Kerja & $\mathrm{p}=0.037$ \\
Mental & $\mathrm{n}=90$ & \\
\hline
\end{tabular}

Hasil analisis korelasi Spearman pada Tabel 10 menunjukkan bahwa terdapat hubungan antara beban kerja mental dengan kebahagiaan di tempat kerja dengan nilai $\mathrm{p}$ value $(0.037)<\alpha(0.05)$. Nilai kekuatan korelasi koefisien yaitu 0.221 artinya memiliki nilai yang sangat lemah dengan arah korelasi negatif sehingga dapat diartikan bahwa responden yang memiliki beban kerja mental berat, maka mempunyai kebahagiaan rendah atau sedang di tempat kerja.

\section{Hubungan Pendapatan dengan Kebahagiaan di Tempat Kerja}

Hasil analisis korelasi Spearman pada Tabel 11 menunjukkan bahwa tidak terdapat hubungan pendapatan dengan kebahagiaan di tempat kerja dengan nilai $\mathrm{p}$-value $(0.782)>\alpha$ (0.05).

Tabel 11. Hubungan Pendapatan dengan Kebahagiaan di Tempat Kerja

\begin{tabular}{lll}
\hline & $\begin{array}{l}\text { Skor Kebahagiaan di } \\
\text { Tempat Kerja }\end{array}$ \\
\hline Pendapatan & $\mathrm{r}=0.030$ \\
& $\mathrm{p}=0.782$ \\
& $\mathrm{n}=90$ \\
\hline
\end{tabular}




\section{PEMBAHASAN}

\section{Karakteristik Responden}

a. Jenis Kelamin

Studi saat ini mengenai jenis kelamin dan kebahagiaan menyatakan bahwa laki-laki dan perempuan mempunyai cara masing-masing untuk mengekspresikan emosi. Perbedaan jenis kelamin menentukan perbedaan penyebab depresi berdasarkan faktor biologis, psikologis dan sosial. Laki-laki mempunyai regulasi emosi yang lebih baik daripada perempuan karena laki-laki cenderung tidak mengekspresikan emosinya (Ratnasari and Suleeman, 2017). Penelitian Meiza (2017) menunjukkan bahwa laki-laki lebih mudah bahagia karena lebih bijaksana dalam menyikapi permasalahan tidak menyenangkan.

Hasil penelitian didapatkan bahwa sebagian besar responden berjenis kelamin perempuan sebesar $57 \%$ yaitu sebanyak 47 dosen. Ketidakseimbangan antara responden laki-laki dan perempuan karena peneliti tidak memperhatikan perbandingan antara jumlah dosen laki-laki dan perempuan. Hasil penelitian menunjukkan bahwa paling banyak yaitu perempuam hal ini bukan berarti bahwa perempuan lebih bahagia di tempat kerja.

b. Usia

Variabel usia dikelompokkan menjadi tiga kategori yaitu dewasa awal pada usia 20-40 tahun, dewasa akhir pada usia 40-60 tahun dan lanjut usia pada usia $\geq 60$ tahun. Hasil pada penelitian ini mendapatkan angka tertinggi pada usia 20-40 tahun maka berada pada kategori dewasa awal. Dewasa awal adalah masa peralihan dari ketergantungan ke masa mandiri baik segi ekonomi, kebebasan menentukan diri sendiri dan pandangan tentang masa depan yang sudah lebih realistis.

Dosen muda biasanya mempunyai idealisme yang kuat dengan memiliki paket kompetensi yang lengkap, rasa ingin tahu yang besar dibidangnya, serta berkomunikasi secara interaktif ketika menyampaikan materi di dalam maupun di luar kelas. Terlepas dari penjelasan di atas, dosen seniorpun mempunyai kelebihan tersendiri misalnya lebih profesional, menghargai waktu dan semangatnya dalam memberikan materi dalam kelas. Oleh karena itu baik dosen muda maupun dosen senior mempunyai style, kelebihan dan kekurangan masing-masing ketika menjadi dosen.

\section{c. Masa Kerja}

Kategori masa kerja pada penelitian ini dikelompokkan menjadi tiga yaitu masa kerja baru <5 tahun, masa kerja sedang 5-10 tahun dan masa kerja lama >10 tahun. Hasil penelitian pada dosen di Universitas Jember menunjukkan bahwa paling banyak dosen mempunyai masa kerja lama yaitu $>10$ tahun sebesar $50 \%$ yaitu sebanyak 45 responden. Dosen yang memiliki masa kerja lama akan lebih berpengalaman dalam melaksanakan tugasnya dan telah mampu dalam menyelesaikan masalah-masalah yang ada (Pertiwi et al., 2017).

\section{d. Golongan}

Golongan adalah tingkat seseorang yang menunjukkan kedudukan pegawai yang dipengaruhi oleh pendidikan terakhir yang dimilikinya. Peraturan Pemerintah No. 17 tahun 2017 tentang Sinkronisasi Proses Perencanaan Dan Penganggaran Pembangunan Nasional. Detail Peraturan menyatakan bahwa golongan pangkat merupakan kedudukan yang menunjukkan tingkat jabatan berdasarkan tingkat kesulitan, tanggung jawab, dampak dan persyaratan kualifikasi pekerjaan yang digunakan sebagai penentuan penggajian.

Pendidikan paling rendah untuk menjadi dosen yaitu magister (S2) atau yang sederajat sehingga ketika pertama kali PNS diangkat menjadi dosen mempunyai golongan III/B yaitu penata muda. Hasil penelitian menunjukkan bahwa mayoritas responden mempunyai golongan III sebesar 83\% sebanyak 75 responden. Hasil penelitian menunjukkan bahwa paling banyak dosen mempunyai golongan III/B sebesar $46.25 \%$ yaitu sebanyak 41 responden.

e. Jabatan Fungsional

Jabatan fungsional dosen atau jabatan akademik dosen merupakan kedudukan yang menunjukkan tugas, tanggung jawab, wewenang dan hak seorang dosen pada perguruan tinggi berdasarkan keahlian tertentu dan bersifat mandiri (Peraturan Menteri Pendayagunaan Aparatur Negara dan Reformasi Birokrasi, 2013). Jabatan fungsional akan berpengaruh dengan beban kerja yang dimiliki dosen karena setiap jabatan fungsional memiliki wewenang dan tanggung jawab serta jumlah angka kredit yang berbeda-beda.

Hasil penelitian ini menunjukkan bahwa paling banyak dosen di Universitas Jember mempunyai jabatan fungsional sebagai lektor 
sebesar $42.5 \%$ yaitu sebanyak 38 responden. Berdasarkan PERMENPAN No.46 Tahun 2013 wewenang dan tanggung jawab lektor dalam mengajar dan membimbing tugas akhir. Jabatan fungsional yang telah diraih oleh dosen digunakan untuk menentukan tunjangan yang akan didapatkan

\section{Beban Kerja Mental}

Pengukuran beban kerja mental pada dosen di Universitas Jember menggunakan angket dari NASA-TLX yang terdiri dari enam sumber beban kerja mental yaitu tuntutan mental, tuntutan waktu, tuntutan fisik, performasi, tingkat usaha dan tingkat frustrasi. Penentuan kategori beban kerja mental dibagi menjadi tiga yaitu beban kerja mental ringan jika responden mendapatkan skor <50, beban kerja mental sedang jika responden mendapatkan skor 50-80 dan beban kerja mental berat jika responden mendapatkan skor $>80$.

Beban kerja mental dosen dipengaruhi oleh beberapa tugas dan tanggung jawab, selain kewajiban menjalankan tridharma perguruan tinggi, beberapa dosen juga mempunyai tugas tambahan tertentu dengan menjabat sebagai wakil dekan, ketua jurusan, sekretaris jurusan, ketua program studi, anggota senat, KOMBI, GPM, dll. Tugas tambahan yang dimiliki dosen tentu akan menambah beban kerja mentalnya sebagai dosen karena terdapat beberapa tanggung jawab tambahan yang harus dijalankannya.

\section{Pendapatan}

Pendapatan merupakan aspek yang perlu dipertimbangkan ketika akan menerima suatu pekerjaan. Hal ini sesuai dengan penelitian Rindila and Sjabadhyni (2014) yang menyatakan bahwa terdapat hubungan antara sikap terhadap uang (pendapatan) dengan kebahagiaan kepada karyawan.

Pada penelitian ini yang digunakan untuk acuan pendapatan adalah daftar gaji yang diterima dosen setiap bulannya di Universitas Jember. Rincian pendapatan yang diperoleh dosen meliputi gaji pokok yang ditentukan sesuai dengan golongan dan masa kerja, tunjangan fungsional, sertifikasi dosen, dan tunjangan struktural.

Hasil penelitian mengenai variabel pendapatan pada dosen di Universitas Jember menunjukkan bahwa sebagian besar responden memperoleh pendapatan pada kategori $\mathrm{Rp}$ 5.000.000,- s/d Rp 10.000.000,- sebesar 62\% yaitu sebanyak 56 responden. Sedangkan terdapat 28 responden yang pendapatannya < Rp 5.000.000,- disebabkan karena berbagai faktor misalnya belum mempunyai jabatan fungsional, tidak menjalani tugas tambahan, tidak mengajukan kenaikan golongan dan jabatan fungsional serta tidak mengajukan sertifikasi dosen.

\section{Kebahagiaan di Tempat Kerja}

Pryce and Jones (2010) mendefinisikan tiga poin kebahagiaan di tempat kerja, yang pertama yaitu secara sadar dosen menanamkan rasa kebahagiaan pada diri sendiri; yang kedua yaitu memaknai bahwa kebahagiaan tidak hanya terjadi pada masing-masing dosen melainkan terjadi antara dosen satu dengan yang lainnya dan poin ketiga yaitu kebahagiaan di tempat kerja tidak berarti bahwa dosen harus merasa baik $100 \%$ dalam setiap waktu atau tidak boleh memiliki perasaan negatif di tempat kerja seperti marah, frustasi, kecewa, gagal, cemburu, atau perasaan negatif lainnnya.

Hasil penelitian ini menunjukkan bahwa mayoritas dosen merasakan kebahagiaan tinggi di tempat kerja tinggi sebesar $89 \%$ yaitu sebanyak 80 responden. Artinya mayoritas dosen merasa bahagia berkarir menjadi dosen dengan menjalankan tridharma perguruan tinggi yang meliputi pengajaran, penelitian dan pengabdian masyarakat.

Hasil penelitian Schiffrin and Nelson (2010) menyatakan bahwa stres dan kebahagiaan mempunyai hubungan yang terbalik, dimana responden yang merasakan tingkat stres yang tinggi mempunyai kebahagiaan yang rendah daripada responden yang mempunyai tingkat stres yang lebih rendah. Hal ini disebabkan karena orang yang mengalami stres akan mempengaruhi kesehatan mentalnya

\section{Hubungan Karakteristik Responden dengan Kebahagiaan di Tempat Kerja}

a. Hubungan Jenis Kelamin dengan Kebahagiaan di Tempat Kerja

Hasil uji analisis statistik menggunakan Chi-square menunjukkan bahwa antara variabel jenis kelamin dengan kabahagiaan di tempat kerja tidak terdapat hubungan yang signifikan, maka tidak ada perbedaan kebahagaiaan di tempat kerja antara laki-laki dan perempuan. Tingkat kepercayaan sebesar 95\% $(\alpha=0.05)$ dan diperoleh hasil nilai sig sebesar 0.314 (nilai $p$ > $0.05)$. 
Seligman (2005) menyatakan bahwa jenis kelamin memiliki hubungan yang tidak konsisten dengan kebahagiaan. Laki-laki dan perempuan mempunyai rata-rata tingkat emosi yang tidak berbeda namun perempuan lebih mudah untuk mengekspresikan perasaannya seperti perasaan bahagia daripada laki-laki. Oleh karena itu beberapa penelitian menunjukkan bahwa variabel jenis kelamin mempunyai hubungan dengan kebahagiaan dan penelitian lain menyatakan bahwa jenis kelamin tidak mempunyai hubungan dengan kebahagiaan di tempat kerja.

b. Hubungan Usia dengan Kebahagiaan di Tempat Kerja

Hasil uji analisis menggunakan Spearman menunjukkan bahwa antara variabel usia dengan kebahagiaan di tempat kerja tidak terdapat hubungan yang signifikan. Tingkat kepercayaan sebesar $95 \% \quad(\alpha=0.05)$ dan diperoleh hasil nilai sig sebesar 0.582 (nilai $p$ > 0.05). Hasil penelitian menunjukkan bahwa sebagian besar responden berada pada kategori dewasa muda yaitu 20-40 tahun dimana pada usia tersebut termasuk usia yang produktif.

Berdasarkan penelitian ini dosen muda yang belum berkeluarga lebih semangat dan antusias di tempat kerja serta menunjukkan performa yang luar bisa karena masih belum memiliki tugas ganda sebagai kepala rumah tangga ataupun ibu rumah tangga apalagi mengurus anak sehingga beliau bisa mencurahkan sebagian besar waktunya untuk menyelesaikan pekerjaan dengan cepat. Sedangkan dosen yang sudah menikah dan mempunyai anak harus pintar dalam manajemen waktu untuk pekerjaan dan keluarga sehingga tidak terjadi tumpang tindih keduanya.

c. Hubungan Masa Kerja dengan Kebahagiaan di Tempat Kerja

Hasil uji analisis menggunakan Spearman menunjukkan bahwa antara variabel masa kerja dengan kebahagiaan di tempat kerja tidak terdapat hubungan yang signifikan. Tingkat kepercaayaan sebesar 95\% $(\alpha=0.05)$ dan diperoleh hasil nilai sig sebesar 0.454 (nilai $p$ > 0.05). Pengalaman kerja ditentukan oleh rentang waktu lamanya seseorang menjalani pekerjaan yang dapat dilihat dari banyaknya tahun sejak diangkat menjadi pegawai pertama kali. Dengan demikian, semakin lama masa kerja dosen, maka akan semakin profesional dalam melaksanakan tugasnya dan akan mewujudkan kinerja yang profesional pula.
Semakin lama dosen mempunyai pengalaman mengajar, maka ia akan mempunyai penguasaan materi perkuliahan pada bidang ilmu yang akan diajarkan kepada mahasiswa dan mampu menerapkan strategi pembelajaran dengan baik.

Hal ini sesuai dengan penelitian Nurhayati and Nasikhin (2017) menyatakan bahwa dosen senior lebih profesional dalam melaksanakan tugas dan kewajibannya dalam perkuliahan. Dosen yang mempunyai masa kerja lama sudah terbiasa dengan rutinitas dosen sehingga tidak menimbulkan stres dan merasakan kebahagiaan di tempat kerja (Nadalis, 2014).

d. Hubungan Golongan dengan Kebahagiaan di

Tempat Kerja

Hasil uji analisis menggunakan uji Spearman menunjukkan bahwa antara variabel golongan dengan kebahagiaan di tempat kerja tidak terdapat hubungan yang signifikan. Tingkat kepercayaan sebesar $95 \%(\alpha=0.05)$ dan diperoleh nilai sig sebesar 0.145 (nilai $\mathrm{p}>$ 0.05).

Golongan yang dimiliki dosen tidak mempunyai hubungan dengan kebahagiaan di tempat kerja namun berhubungan dengan pendapatan yang diperoleh dosen, karena golongan menentukan gaji pokok

Penentuan gaji berdasarkan golongan tidak mempunyai perbedaan yang terlalu signifikan. Selain itu juga terdapat perbedaan pajak pendapatan pada golongan III dan IV, pada golongan III dikenakan potongan pajak 5\% dan pada golongan IV dikenakan potongan pajak $15 \%$.

Salah satu penyebab golongan tidak berhubungan dengan kebahagiaan di tempat kerja diduga karena terdapat beberapa responden yang sudah lama tidak memproses kenaikan golongan karena administrasi yang rumit sehingga beliau tidak terlalu mempermasalahkan jika tidak bisa naik golongan. Hal ini sesuai dengan penelitian Toisuta (2017) yang menyatakan bahwa kurangnya peluang naik golongan pangkat dapat menjadi penyebab stres, sedangkan individu yang merasa stres dapat menghilangkan kebahagiaan

e. Hubungan Jabatan Fungsional dengan Kebahagiaan di Tempat Kerja

Hasil uji analisis menggunakan Chi Square menunjukkan bahwa antara variabel jabatan fungsional dengan kebahagiaan di tempat kerja tidak terdapat hubungan yang siginifikan. Tingkat kepercayaan $95 \% \quad(\alpha=0.05) \quad$ dan 
diperoleh nilai sig sebesar 0.373 (nilai $\mathrm{p}>$ 0.05).

Jabatan fungsional tidak memiliki hubungan dengan kebahagiaan di tempat kerja hal ini disebabkan semakin tinggi jabatan fungsional yang dimiliki dosen maka wewenang dan tanggung jawab akan semakin berat selain itu pemenuhan jumlah angka kredit menjadi lebih banyak.

Jabatan fungsional tidak memiliki hubungan dengan kebahagiaan di tempat kerja karena semakin tinggi jabatan fungsional yang dimiliki maka akan menambah beban kerja dosen. Jabatan fungsional yang dimiliki dosen dapat digunakan untuk menentukan tunjangan fungsional karena setiap jabatan fungsional mempunyai nominal yang berbeda-beda antara lain $\mathrm{Rp}$ 375.000,- untuk asisten ahli, Rp 700.000,- untuk lektor, Rp 900.000 untuk lektor kepala dan Rp 1.350.000,- untuk guru besar yang diterima setiap bulannya

\section{Hubungan Beban Kerja Mental dengan Kebahagiaan di Tempat Kerja}

Hasil uji analisis menggunakan Spearman menunjukkan bahwa terdapat hubungan yang signifikan antara variabel beban kerja mental dengan kebahagiaan di tempat kerja. Tingkat kepercayaan $95 \%(\alpha=0.05)$ dan diperoleh hasil sig sebesar 0.037 (nilai $\mathrm{p}<0.05$ ). Kekuatan korelasi kedua variabel yaitu 0.221 berarti kekuatan korelasi yang dimiliki variabel berada pada tingkat korelasi yang sangat lemah. Arah korelasi kedua variabel bernilai negatif sehingga dapat diartikan bahwa responden yang memiliki beban kerja mental ringan maka akan mempunyai kebahagiaan tinggi di tempat kerja dan sebaliknya.

Beban kerja mental yang lebih tinggi dari pada kemampuan tubuh maka pada tahap awal dapat menyebabkan perasaan tidak nyaman, kelelahan, cedera, kecelakaan kerja, penyakit akibat kerja dan pada tahap akhir dapat menyebabkan produktivitas menurun. Namun sebaliknya, jika beban kerja yang dimiliki rendah dari kemampuan tubuh, maka akan terjadi (under stress), kejenuhan, kebosanan, kelesuan dan kurang produktif. Hal ini sesuai dengan penelitian Pertiwi et al. (2017) yang menyatakan bahwa beban kerja mental berat akan menyebabkan produktivitas rendah pada dosen sehingga dosen harus dapat mengatur waktu untuk melaksanakan tridharma perguruan tinggi secara maksimal.

Beban kerja yang berlebihan seperti terjebak dalam siklus bekerja seharian atau mayoritas menghabiskan waktu di tempat kerja maka dapat mengorbankan kesejahteraan, kesehatan, kesuksesan bahkan keluarga. Terlalu banyak bekerja adalah suatu jebakan, ketika menjadikan bekerja sebagai solusi untuk menghilangkan stres maka itu hanya akan meningkatkan beban kerja dan dapat meningkatkan tekanan. Cara untuk mendapatkan kebahagiaan yaitu merubah pola pikir bahwa bahwa beban kerja berlebihan itu tidak baik dan akan menemukan kebahagiaan ketika suatu pekerjaan dapat diselesaikan. Kebahagiaan adalah hak asasi manusia sehingga sebaik mungkin dapat menciptakan kebahagiaan di tempat kerja (McKee, 2017).

\section{Hubungan Pendapatan dengan Kebahagiaan di Tempat Kerja}

Hasil uji analisis menggunakan Spearman menunjukkan bahwa tidak terdapat hubungan yang signifikan antara variabel pendapatan dengan kebahagiaan di tempat kerja. Tingkat kepercayaan sebesar $95 \% \quad(\alpha=0.05)$ dan diperoleh nilai sig sebesar 0.782 (nilai $\mathrm{p}>$ $0.05)$.

Hasil penelitian ini menunjukkan bahwa pendapatan tidak berhubungan dengan kebahagiaan di tempat kerja. Hal ini kemungkinan disebabkan karena orientasi dosen bukan karena ingin mendapatkan pendapatan yang besar namun lebih condong pada berkarir menjadi dosen merupakan pekerjaan mulia yang dapat membantu mencerdaskan generasi penerus bangsa selain itu beliau juga telah menikmati profesinya sehingga pendapatan yang didapat tidak dijadikan sebagai tolak ukur kebahagiaan. Faktor lain yang menyebabkan pendapatan tidak berhubungan dengan kebahagiaan di tempat kerja beberapa responden mempunyai pekerjaan lain seperti konsultan, dosen di PTS, dan mempunyai bisnis yang kemungkinan akan mendapatkan pendapatan yang lebih besar sehingga dapat memenuhi kebutuhan hidupnya.

\section{KESIMPULAN DAN SARAN}

\section{Kesimpulan}

Berdasarkan hasil penelitian yang telah dilakukan oleh peneliti, maka diperoleh kesimpulan sebagai berikut: Karakteristik individu responden paling banyak berada pada kategori dewasa muda yaitu 20-40 tahun (57\%), variabel masa kerja paling banyak berada pada 
kategori masa kerja lama >10 tahun (50\%), variabel golongan mayoritas mempunyai golongan III (83\%) dan sebagian besar responden mempunyai jabatan fungsional lektor (42\%). Sebagian besar beban kerja mental responden berada pada kategori beban kerja mental sedang (78\%) dan 4\% mempunyai beban kerja mental berat. Pendapatan responden mayoritas berada pada rentang $\mathrm{Rp} 5.000 .000$,s/d Rp 10.000.000,- (62\%). Pada variabel kebahagiaan di tempat kerja mayoritas responden mempunyai kebahagiaan tinggi di tempat kerja.

Karakteristik individu (jenis kelamin, usia, masa kerja, golongan dan jabatan fungsional) tidak terdapat hubungan yang signifikan dengan kebahagiaan di tempat kerja. Variabel pendapatan tidak memiliki hubungan dengan kebahagiaan di tempat kerja. Terdapat hubungan yang signifikan antara beban kerja mental dengan kebahagiaan di tempat kerja.

\section{Saran}

Bagi Universitas Jember diharapkan dapat meningkatkan tata kelola lembaga yang lebih baik dengan menerapkan unsur transparansi, pengorganisasian, partisipasi, responsivitas, akuntabilitas dan kepemimpinan. Selain itu juga diharapkan dapat mengevaluasi setiap semester kesesuaian pengisian BKD dengan beban kerja yang sebenarnya yang ditanggung dosen. Bagi bapak/ibu dosen diharapkan dapat menerapkan manajemen waktu yang baik, tidak menundanunda pekerjaan, merencanakan jumlah beban kerja serta membuat skala prioritas.

Bagi peneliti selanjutnya, perlu untuk memperbanyak jumlah responden, membandingkan dosen PNS dan non PNS serta menambahkan variabel lain yang berhubungan dengan kebahagiaan di tempat kerja seperti budaya organisasi, hubungan dengan rekan kerja dan pimpinan, lingkungan kerja fisik pengembangan diri serta prestasi.

\section{DAFTAR PUSTAKA}

1] Dewi, I. R. 2016. Hubungan Beban Kerja Mental dengan Stres Kerja Pada Dosen di Universitas Jember. Universitas Jember.

2] Guswandy, R., 2017. Akankah Gaji Besar Membawa Kebahagiaan. URL https://www.linovhr.com/akankah-gajibesar-membawa-kebahagiaan/ . accessed 7 March 2019.
3] Hills, P., Argyle, M. 2002. The Oxford Happiness Questionnaire: A compact scale for the measurement of psychological well-being. Personality and Individual Differences 33, 1073-1082.

4] Lintangsari, A.A. 2012. Hubungan antara Employee Satisfaction dan Budaya Organisasi dengan Employee Engagement pada Karyawan Tetap PT. BPD Jawa Tengah Cabang Utama Semarang.

5] McKee, A. 2017. How to Be Happy at Work: The Power of Purpose, Hope and Frienship. Harvard Business Press.

6] Meiza, C. 2017. Perbedaan Kebahagiaan pada Guru Berstatus PNS dan Honorer. Jurnal Psikologi 9.

7] Menteri Hukum dan Hak Asasi Manusia. 2005. Undang - Undang Republik Indonesia Nomor 14 Tahun 2005 Tentang Guru dan Dosen. Indonesia: Jakarta.

8] Nadalis, E. C. 2014. Hubungan Usia, Masa Kerja dan Beban Kerja Dengan Stress Kerja Karyawan. Jurnal Ilmu Manajemen (JIM) 2

9] Nurhayati, D., Nasikhin, M. 2017. Analisis Pengaruh Masa Kerja, Beban Mengajar, dan Iklim Organisasi Terhadap Kinerja Profesionalisme Dosen STKIP PGRI Pasuruan. Jurnal Ilmiah Edukasi \& Sosial $5,28-39$.

10] Peraturan Menteri Pendayagunaan Aparatur Negara dan Reformasi Birokrasi. 2013. PERMENPAN No. 46 Tahun 2013 Tentang Perubahan atas Peraturan Menteri Pendayagunaan Aparatur Negara dan Reformasi Birokrasi Nomor 17 Tahun 2013 Tentang Jabatan Fungsional Dosen dan Angka Kreditnya. Indonesia: Jakarta.

11] Pertiwi, E.M., Denny, H.M., Widjasena, B. 2017. Hubungan antara Beban Kerja Mental dengan Stres Kerja Dosen di Suatu Fakultas. Jurnal Kesehatan Masyarakat (eJournal) 5, 260-268.

12] Priyono, Marnis. 2008. Manajemen Sumber Daya Manusia. Zifatama Publisher, Sidoarjo.

13] Pryce, J., Jones. 2010. Happiness at Work Maximizing Your Psychological Capital For Success. Wiley Blackwell, United Kingdom.

14] Ratnasari, S., Suleeman, J. 2017. 
Perbedaan regulasi emosi perempuan dan laki-laki di perguruan tinggi. Jurnal Psikologi Sosial 15, 35-46.

15] Rindila, N., Sjabadhyni, B. 2014. Hubungan Antara Sikap Terhadap Uang dan Kebahagiaan pada Karyawan. Universitas Indonesia.

16] Schiffrin, H.H., Nelson, S.K. 2010. Stressed and happy? Investigating the relationship between happiness and perceived stress. Journal of Happiness Studies 11, 33-39.

17] Seligman, M. 2005. Authentic Happiness : Menciptakan kebahagiaan dengan psikologi positif. PT. Mizan Pustaka, Bandung.
18] Sulistyowati, A., Muazansyah, I. 2018. Pengaruh Beban Kerja Dan Kesejahteraan Dosen Terhadap Kepuasan Kerja Dan Burnout. JPAP: Jurnal Penelitian Administrasi Publik 4, 914-919.

19] Toisuta, D. 2017. Hubungan Kepuasan Kerja, Stres Guru Dengan Kebahagiaan Guru Pendidikan Agama Sekolah Menengah di Kota Ambon. Satya Widya 33, 11-28.

20] Veenhoven, R., 2006. Data Book of Happiness. Erasmus University Rotterdam, Rotterdam. 